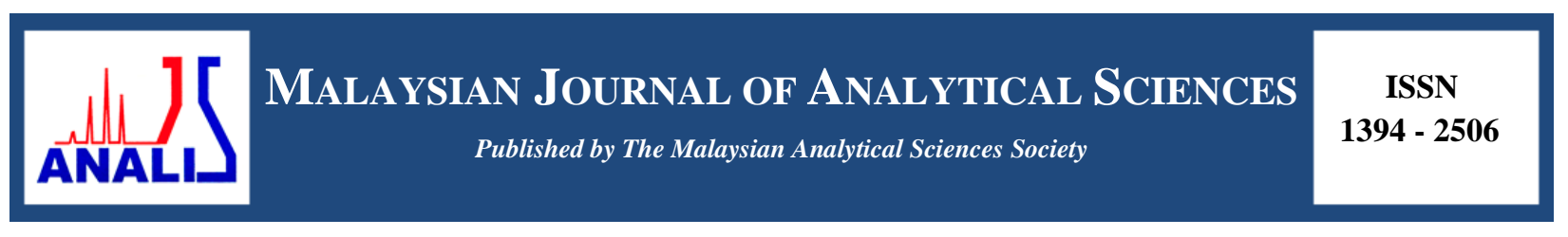

\title{
ENERGY MANAGEMENT STRATEGY FOR A FUEL CELL/ULTRACAPASITOR/BATTERY HYBRID SYSTEM FOR PORTABLE APPLICATIONS
}

\author{
(Strategi Pengurusan Tenaga bagi Sistem Hibrid Sel Bahan Api/ Ultrakapasitor/Bateri \\ untuk Aplikasi Mudah Alih)
}

\author{
Siti Afiqah Abd. Hamid ${ }^{1}$, Edy Herianto Majlan ${ }^{1 *}$, Ros Emilia Rosli ${ }^{1}$, Wan Ramli Wan Daud ${ }^{1}$, \\ Ramizi Mohamed ${ }^{2}$, Teuku Husaini ${ }^{1}$, Ramli Sitanggang ${ }^{3}$ \\ ${ }^{1}$ Fuel Cell Institute \\ ${ }^{2}$ Department of Electrical and System Engineering, Faculty of Engineering \& Built Environment \\ Universiti Kebangsaan Malaysia, 43600 UKM Bangi, Selangor, Malaysia \\ ${ }^{3}$ Department of Chemical Engineering, Faculty of Industrial Engineering, \\ Universitas Pembangunan Nasional "Veteran” Yogyakarta, Yogyakarta 55283, Indonesia \\ *Corresponding author: edy@ukm.edu.my
}

Received: 5 February 2016; Accepted: 22 April 2016

\begin{abstract}
A proton exchange membrane (PEM) fuel cells (FCs) with ultracapacitor (UC) and battery (BT) hybrid system has fast transient response compare to stand alone FCs. This hybrid system is promising candidates for environmentally friendly alternative energy sources. An energy management system design and control strategy was introduced in this study. The energy management strategy FC/UC/BT hybrid system model has been developed and the control strategy was programmed in the LabVIEW ${ }^{\mathrm{TM}}$ environment and implemented using National Instrument (NI) devices. The energy management strategy is able to manage the energy flow between the main power source (FCs) and auxiliary sources (UC and BT). To control the hybrid system and achieved proper performance, a controller circuit was developed with the three energy sources aligned in parallel to deliver the requested power. The developed model demonstrates the proportion power from the FC, UC and BT under various load demand. Experimental results demonstrate that FC/UC/BT hybrid system operated automatically with the varying load condition. The experimental results are presented; showing that the proposed strategy utilized the characteristic of both energy storage devices thus satisfies the load requirement.
\end{abstract}

Keywords: proton exchange membrane fuel cell, ultracapacitor, battery, hybrid energy system, energy management strategy

\begin{abstract}
Abstrak
Sistem hibrid sel bahan api (FC) membran penukaran proton (PEM) dengan ultrakapasitor (UC) dan bateri (BT) mempunyai tindak balas yang lebih cepat berbanding FC sahaja. Sistem hibrid adalah salah satu sumber tenaga alternatif mesra alam yang amat berpotensi. Satu reka bentuk sistem pengurusan tenaga dan strategi kawalan telah diperkenalkan dalam kajian ini. Model strategi pengurusan tenaga sistem hibrid FC/UC/BT telah dibangunkan dan strategi kawalan telah diprogramkan dalam perisian LabVIEW $^{\text {TM }}$ dan dilaksanakan dengan menggunakan peranti instrument Nasional (NI). Strategi pengurusan tenaga ini mampu untuk menguruskan aliran tenaga di antara sumber kuasa utama (FC) dan sumber kuasa tambahan lain (UC dan BT). Untuk mengawal sistem hibrid dan mencapai prestasi yang sewajarnya, litar pengawal telah dibangunkan dengan tiga sumber tenaga sejajar selari untuk menyediakan permintaan kuasa. Model yang dibangunkan menunjukkan keseimbangan jumlah kuasa daripada FC, UC dan BT di bawah pelbagai permintaan beban. Keputusan eksperimen menunjukkan bahawa sistem hibrid FC/UC/BT beroperasi secara automatik dengan keadaan beban yang berbeza-beza. Keputusan eksperimen dibentangkan,
\end{abstract}


menunjukkan bahawa strategi yang dicadangkan memanfaatkan ciri kedua-dua sumber kuasa tambahan dengan itu memenuhi keperluan beban.

Kata kunci: Sel bahan api membran penukaran proton, ultrakapasitor, bateri, sistem tenaga hibrid, strategi pengurusan tenaga

\section{Introduction}

Research in the field of alternative/renewable energy sources increasingly become the focus of many researchers, in an attempt to find a novel and environmentally friendly energy source that does not rely on fossil fuels, to replace internal combustion engines for use in vehicles. This research, besides ensuring energy supplies for the future, it may also reduce the pollution caused by fossil fuels. As an alternative to the internal combustion engine, fuel cell technology has advantages in many aspects that make it the preferred choice of researchers [1-5]. PEMFC is one that has been applied widely, from a stand-alone system and a hybrid system, especially in vehicle applications, power units, and electronic devices mobile. A stand-alone PEMFC system unfortunately cannot satisfy the sudden load variation in vehicles due to its slow dynamic response. The voltage decreases drastically and this situation evidently harmful to the PEMFC [6]. Most electronic devices and vehicles require a stabilized power source and fast transient response. Combining a PEMFC with an auxiliary power source would improve the operational efficiency and dynamic response of the system and extend the PEMFC lifetime. The auxiliary energy source usually uses an energy storage device that can store the excess energy from the PEMFC (charge) and support the load demand when needed (discharge). This system includes power electronics and a controller for the energy management system. The concept of hybrid technology was widely embraced for the conventional internal combustion engine (ICE) to minimize the peak power possible for acceleration, allow for optimal operational efficiency [7], recapture kinetic energy when braking (regenerative braking), and, more importantly, conserve fuel. In the literature [8-11], the preferred energy storage devices for PEMFCs are BTs and UCs because they have their own unique characteristics. BTs can charge rapidly and have excellent energy density [12] and a higher specific energy than UCs, thus supplying extra power for a longer period of time. And the key advantage of UCs is their ability to charge and discharge for almost an unlimited number of cycles, have relatively high power densities and long lifetimes, are cheaper and environmentally safe, can be operated at high or low temperatures without maintenance, and can deliver high power/currents in a short time without incurring structural damage [12].

The energy management strategy and controller are important factors in hybridizing PEMFCs and energy storage devices. In the past, researchers extensively studied hybrid system technologies using various control strategies to manage the energy distribution between the FC and auxiliary energy source. The strategy for each system, which can affect the system performance, was developed based on a certain objective (for example, the fuel consumption) within the constraints of the device used (BT state of charge limits, power limits, etc.) [13]. Hybrid systems capture the best features of each energy resource and can provide stable and quality electricity.

\section{Materials and Methods}

Basically, in active hybrid, several configurations can be used to achieve power sharing in PEMFC hybrid systems. Uzunoglu and Alam developed the simplest parallel operating structure for vehicle applications, which was direct integration by Honda [14]. The auxiliary power source is directly connected in line between the FC and the load as shown in Figure 1. This configuration is quite attractive because it does not require a high-power DC/DC converter, and thus, the complexity, cost, weight, and volume of the system are significantly reduced. Therefore, we modified the direct integration configuration to include three energy sources.

After choosing an appropriate system configuration, the components should be selected carefully. Our objective was to design a low-cost system with a simple configuration that did not involve a complex mathematical algorithm and that had an easy-to-follow circuit arrangement. The system uses an active hybrid with one buck DC/DC converter directly integrated into the system. The power demand of the electronic load is satisfied by the combination of the FC, UC and BT. The resultant load current and output power can be expressed in equation 1 and 2 as given below:

$$
I_{L}=I_{F C}+I_{U C}+I_{B T}
$$




$$
P_{L}=V_{L} I_{L}
$$

where $I_{L}$ is load current, $I_{F C}$ is FC current, $I_{U C}$ is UC current and $I_{B T}$ is BT current. While $P_{L}$ is load power and $V_{L}$ is load voltage respectively.

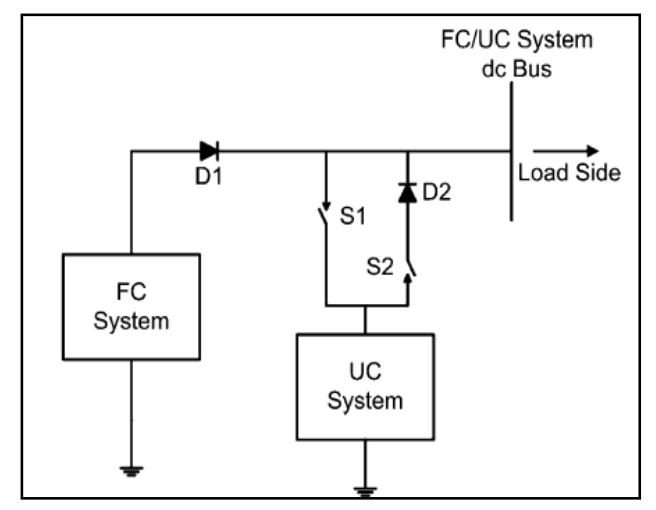

Figure 1. PEMFC/UC hybrid power system [14]

\section{Energy management system controller}

National Instruments Compact Field Point (cFP) is the energy management system controller. The power control is based on the output voltage from each energy source and the resulting load voltage. The strategy is programmed using the LabVIEW ${ }^{\mathrm{TM}}$ software and then implemented using the cFP devices combined with the controller circuit. The input and output modules used in this work were cFP-RLY-425 (relay module) and cFP-AI-102 (analog input module for the voltage). This relay module was used to control the power of the mechanical relay in the controller circuit. Approximately $5 \mathrm{~W}$ were required to turn on the mechanical relay in the controller circuit with a rated voltage of $12 \mathrm{~V}$ and a rated current of $417 \mathrm{~mA}$. The cFP-AI-102 module on the other hand acts as a voltage indicator to the controller program in LabVIEW ${ }^{\mathrm{TM}}$. The PEMFC, BT, UC, and load voltages and currents were also measured using this device.

\section{Controller circuit}

The controller circuit (Figure 2) is the electrical board that links the energy sources, controller device, and electronic devices to the load. To give the specific load requirements for this study, the DC electronic load is employed. The controller circuit consists of four mechanical relays, three diodes, four DC buses, and a $12 \mathrm{~V}$ DC/DC converter. The mechanical relay serves as the switch to allow power to flow from the UC and/or BT to support the FC or to charge and discharge the UC and BT. The diode acts as a blocking device to prevent the power from flowing in the wrong direction. The voltage drop from the diode is only $0.7 \mathrm{~V}$, which is negligible. Moreover, the DC bus is a connecting bar where all the power sources connect to the DC/DC converter for ease of plugging into and out of the power source. The DC/DC converter is the voltage regulator that maintains the voltage output from the DC bus at $12 \mathrm{~V}$. This controller circuit manages the power transfer between these three power sources.

\section{Energy storage device}

UC and BT energy storage devices are used in the proposed hybrid system. These two energy sources are combined with a PEMFC to be in line with the power generator unit. In this study, we use $350 \mathrm{~F}, 2.5 \mathrm{~V}$ Boostcap UCs from Maxwell Technologies. For the experiment, a nominal voltage of $12 \mathrm{~V}$ is required; therefore, six single $350 \mathrm{~F}, 2.5 \mathrm{~V}$ Boostcap UCs are connected in series. The equivalent series capacitance is $58.333 \mathrm{~F}$. As the UCs discharge, their voltage drops. To manage the UC charging, the voltage limits for the controller circuit program were set to $12 \mathrm{~V}$, as suggested by the manufacturer. 
A $12 \mathrm{~V}$, 5A H nanogel BT (model YTZ5S-BS, Koyoko) are used for the second energy storage device. It is a plugand-play product, meaning no acid or BT water needs to be added. The manufacturer suggests that the BT voltage remain at $12.5 \mathrm{~V}$ or higher to maintain its excellent mode operation. The charging settings are $13 \mathrm{~V}-15 \mathrm{~V}$ and $0.8 \mathrm{~A}$ - $1.2 \mathrm{~A}$. In this work, the BT is charged by the power output from the DC/DC converter, which is limited to a maximum of $12 \mathrm{~V}$.

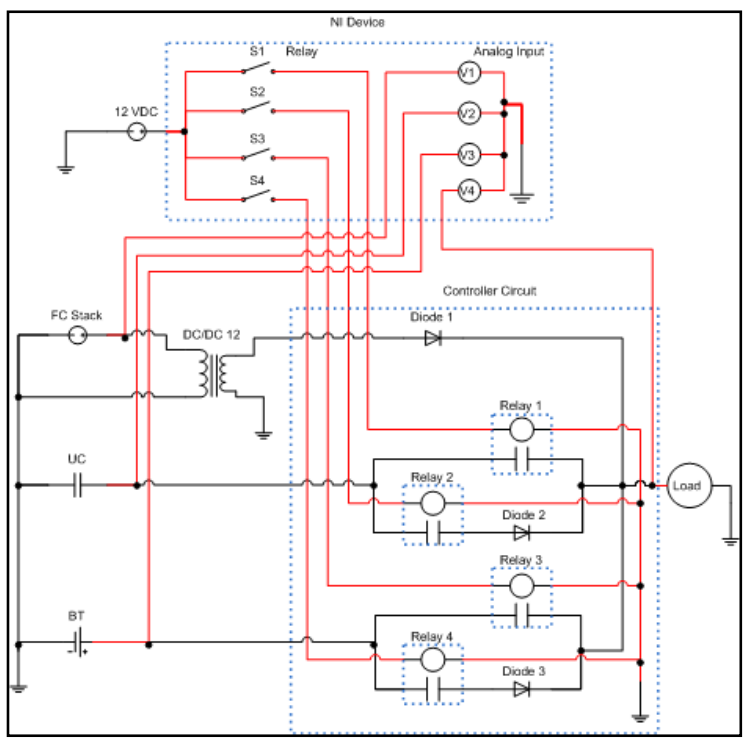

Figure 2. Controller's electrical circuit of the energy management system

\section{PEMFC stack}

The advantages of using PEMFC are the simplicity, high efficiency, lightweight design, smaller size, ease of integration and use, few peripherals, and good reliability. In this work, a model H-100 PEMFC manufactured by Horizon Technology is used. This PEMFC is an open-cathode FC with 24 cells stacked together. The nominal voltage capacity of the PEMFC stack is $14.4 \mathrm{~V}$ at a current of approximately $7.2 \mathrm{~A}$ and typically capable of producing $100 \mathrm{~W}$ at a rated power. The stack efficiency at $14.4 \mathrm{~V}$ is $40 \%$, as stated in the manufacturer's manual.

\section{Energy management strategy}

Currently, energy management is an absolute necessity. FCs sometimes supplies more energy than necessary, and the excess energy should be used to charge the auxiliary energy source. Occasionally, the FC does not supply enough energy. Then, the auxiliary energy source is partially depleted, but the power demand is high, making it necessary to satisfy the load demand rather than charge the auxiliary energy source. The energy management strategy proposed in this paper is described below and was based on voltage regulation:

a) The system measures the load voltage. If the load voltage is greater than $12 \mathrm{~V}$, then the system measures the UC voltage to determine if it is also greater than $12 \mathrm{~V}$. The system charges the UC if the voltage is below $12 \mathrm{~V}$. If the UC voltage is $12 \mathrm{~V}$ or higher, the system checks the BT voltage and charges the BT if its voltage is below $12 \mathrm{~V}$. If all voltages are at least $12 \mathrm{~V}$, the excess energy is delivered to the load only.

b) If the measured load voltage is less than $10 \mathrm{~V}$, both the UC and BT switches are opened to supply the needed energy. Otherwise, if the load voltage is between $10 \mathrm{~V}$ and $12 \mathrm{~V}$, only the UC switch is opened because the UC can charge and discharge quickly. 


\section{Test bench}

The test bench setup as in Figure 3 consists of the three energy sources (PEMFC, UC and BT), controller device, and circuit described previously. The controller device requires a computer to monitor the performance of the hybrid system and the DC electronic load, which is the load demand. The electronic load was programmed to act as the current load to replicate the current required on most application devices. The load profile used in this study is based on one from the literature [15] to prove that this configuration and energy management strategy can satisfy the load profile.

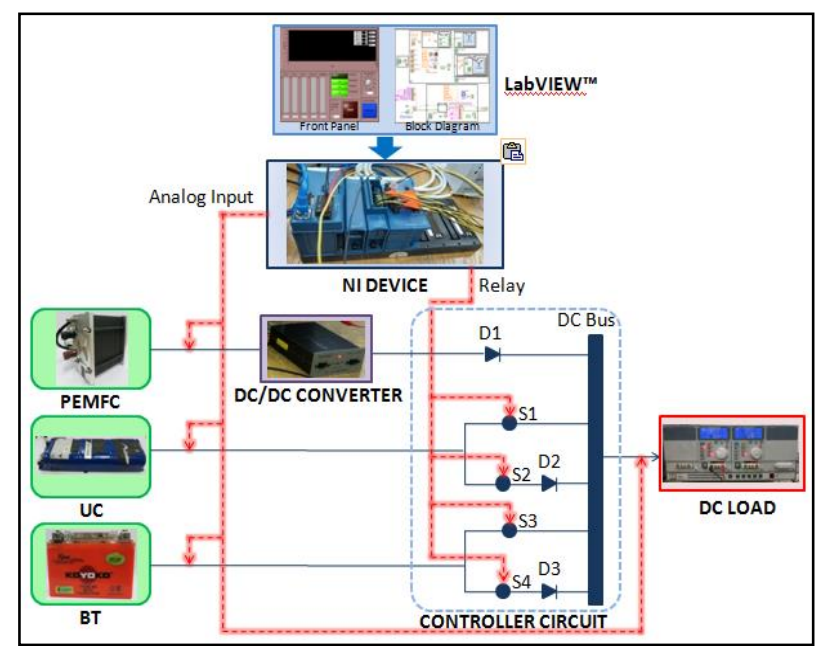

Figure 3. Diagram of the PEMFC/UC/BT hybrid energy management system.

\section{Results and Discussion}

In this study, the load profile used is a series of step signals to represent the load-required power presented in Figure 4a. The load profile can be used to represent the power consumed in most electronic applications. The controller is then manage the load sharing between FC, UC and BT. Initially, the step power starts at $1.1 \mathrm{~W}$, which is the power required to start most electronic devices. The power increases to $3.3 \mathrm{~W}$ at $31 \mathrm{~s}$ and rises to $43 \mathrm{~W}$ at $61 \mathrm{~s}$, then decreases to $22 \mathrm{~W}$ at $91 \mathrm{~s}$. At $121 \mathrm{~s}$, the power increases again to $43 \mathrm{~W}$. The system begins to overload at $151 \mathrm{~s}$ when the power increases to $60 \mathrm{~W}$, and the peak power of about $65 \mathrm{~W}$ is reached at $153 \mathrm{~s}$. The power slowly decreases to $53 \mathrm{~W}$ at $211 \mathrm{~s}$ and further decreases to $37 \mathrm{~W}$ at $241 \mathrm{~s}$. Then, the system increases the power demand to $43 \mathrm{~W}$ at $271 \mathrm{~s}$ and to $57 \mathrm{~W}$ at $301 \mathrm{~s}$. The power then decreases to $6.7 \mathrm{~W}$ at $331 \mathrm{~s}$ and goes to $1.1 \mathrm{~W}$ at $361 \mathrm{~s}$. The performance of the developed energy management strategy of PEMFC/UC/BT hybrid system, FC, UC, BT and load power, voltage and current as a function of time are illustrated in Figure 4 until Figure 6.

a)

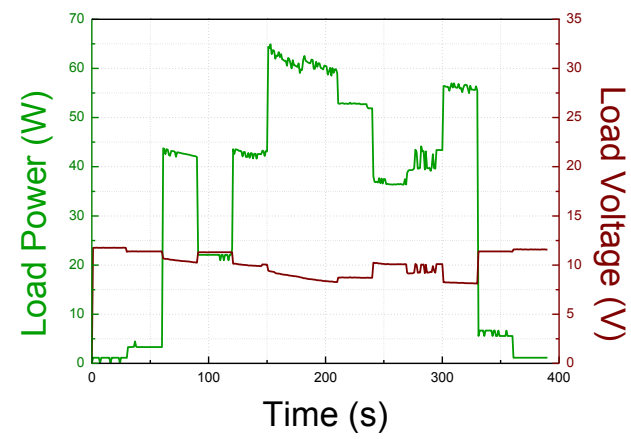

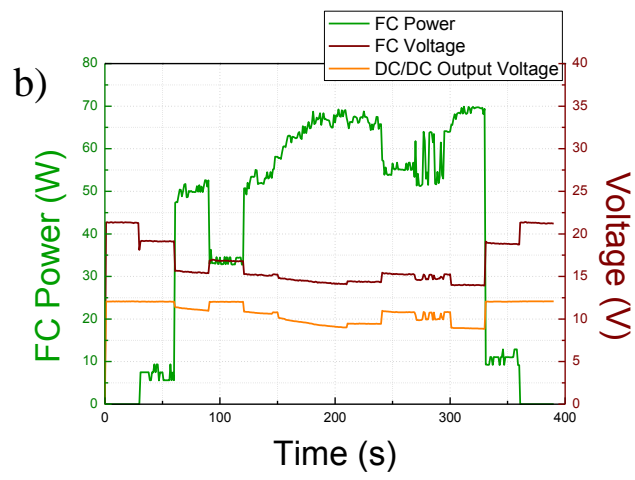

Figure 4. Power and voltage of a) Load and b) Fuel Cell 
a)

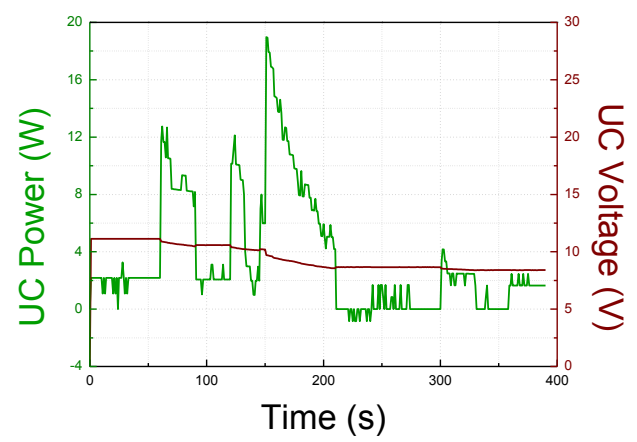

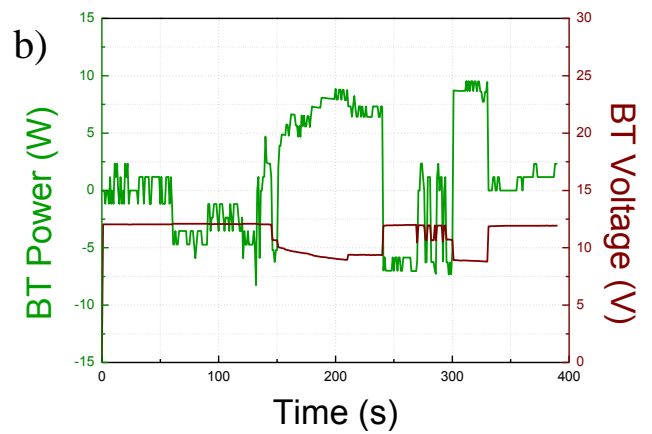

Figure 5. Power and voltage of a) Ultracapasitor and b) Battery

a)

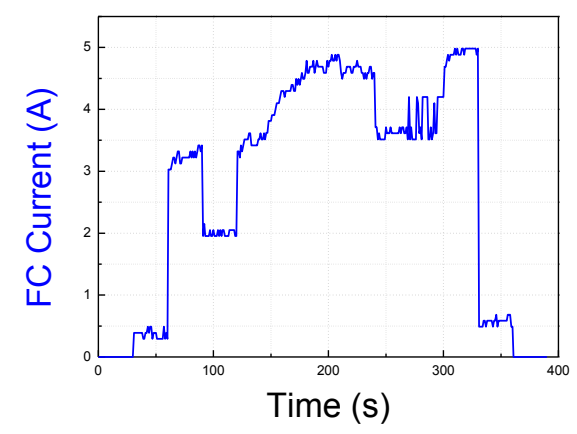

c)

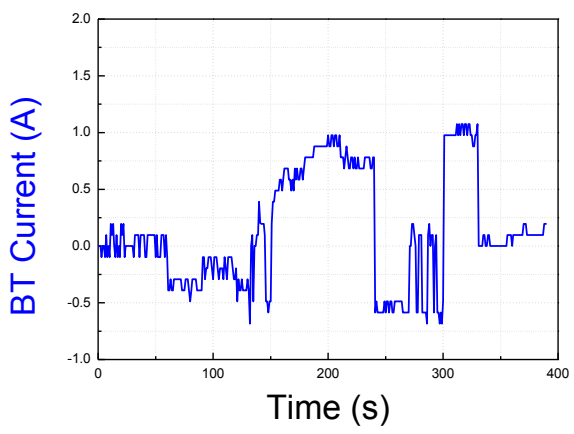

b)

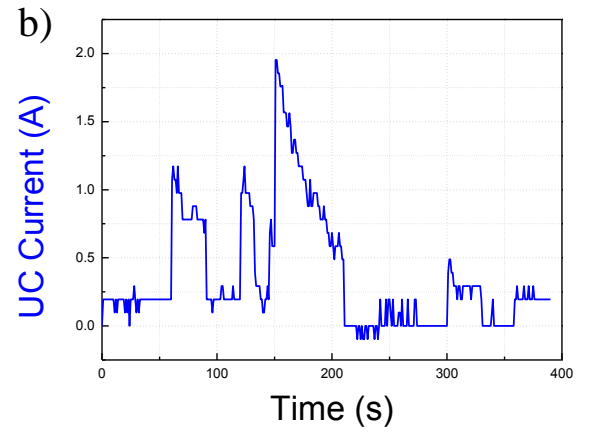

d)

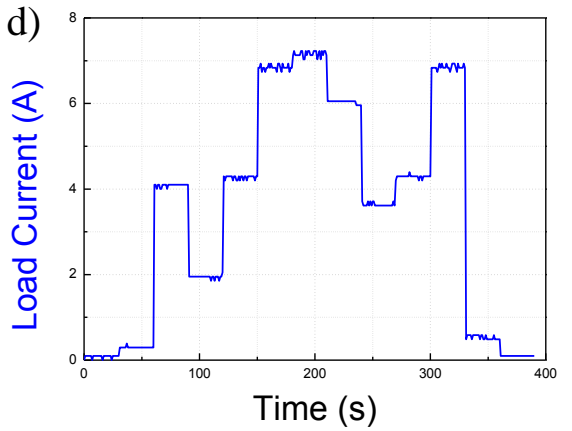

Figure 6. Current of a) Fuel Cell; b) Ultracapasitor; c) battery and d) Load

The FC, however, needs to be regulated by the DC/DC converter to ensure that the output power was constant at 12 $\mathrm{V}$. The efficiency of the FC power was reduced by $15 \%$ due to the DC/DC converter, and the input voltage is between $14 \mathrm{~V}$ and $24 \mathrm{~V}$. If the FC voltage is lower than $14 \mathrm{~V}$, the DC/DC converter output is considerably less than $12 \mathrm{~V}$, and the UC or BT is required to supply the remaining needed power. The FC system successfully maintained the output voltage above $14 \mathrm{~V}$, but due to the high load demand between 151 to $240 \mathrm{~s}$ and between 301 to $330 \mathrm{~s}$ illustrate in Figure 6a where the current draw from FC are near to $5 \mathrm{~A}$, the system voltage at the DC bus fell below $10 \mathrm{~V}$. The resulting FC voltage decreases as the power increases, as shown in Figure $4 \mathrm{~b}$ is due to the basic characteristic of FC. However, its support the load demand base portion without facing a crucial transient changes. 
The maximum power generated by the FC is approximately $69 \mathrm{~W}$ when the load at peak power about $60 \mathrm{~W}$. On contrarily, the load profile used in literatures $[12,14]$ research are based on urban dynamometer driving schedule (UDDS) drive cycle. Thus, the power demand varied all the time. Both research are in hybrid system for FC, only differ with the energy storage unit. In [12] the energy storage unit are the same with this paper, which combine UC and BT. While in study reported by Uzunoglu and Alam [14], it used only UC as the energy storage unit. In Figure $7 \mathrm{a}$ and $7 \mathrm{~b}$ show the FC output power of both system and clearly present that the combination of UC and BT greatly reduce the transient power demand face by FC.

The energy stored in the UC is depleted between $151 \mathrm{~s}$ to $390 \mathrm{~s}$, as shown by the decrease in the voltage during this period in Figure 5a. The energy strategy dictates that the UC provide the necessary energy to the system by discharging and high current draw from UC as in Figure 6b. The UC then starts to charge for a short while then discharge until end of experiment (as mentioned before, UC only can support power for a short time) after $241 \mathrm{~s}$. In contrast, the BT begins to discharge at $141 \mathrm{~s}$. In the meantime, the BT charges and discharges as the current demand changes and support FC longer to satisfied the load, this utilize the BT characteristic of high energy densities. The details are presented in Figure 5b for BT power and voltage while in Figure $6 \mathrm{c}$ the current draw presented. This result provides good advantages in commercializing FC with the help of hybrid system. While decreasing the size and cost of the FC, the hybrid system also prevent the FC from operate in fuel starvation situation.

a)

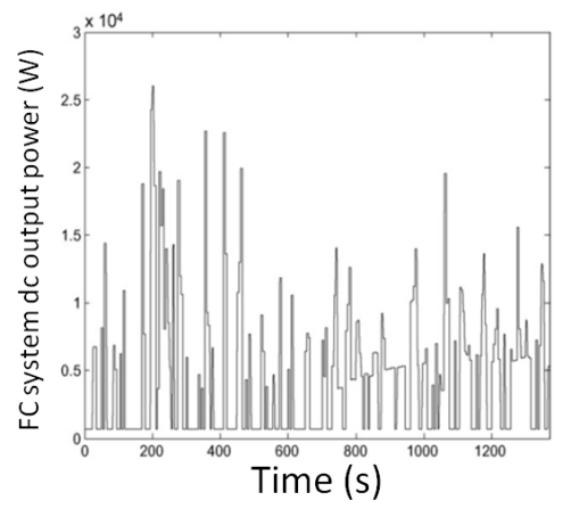

b)

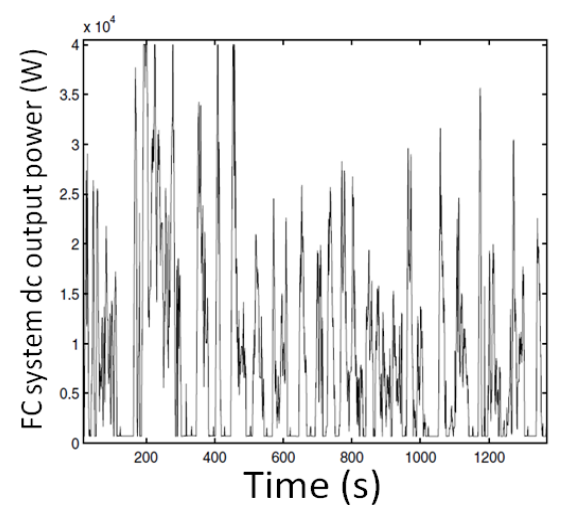

Figure 7. The FC output power variation according to UDDS of a) FC/UC/BT hybrid system [12] and b) FC/UC hybrid system [14].

The hybrid energy management system directs the flow of energy from the energy source to the load system successfully. As shown by the resulting current of the hybrid system in Figure 6d. The system on the other hand did not maintain the operating voltage at $12 \mathrm{~V}$ (Figure 4a). The single DC/DC converter however was not sufficient for this system, and an additional DC/DC converter is needed to stabilize the UC and/or BT voltage output, making the system more costly.

The test was continued further by increasing the current step by $0.5 \mathrm{~A}$ for every $30 \mathrm{~s}$ to determine the maximum operating current of this system. The objective of development a PEMFC/UC/BT hybrid system was to develop a system that utilizes a PEMFC as the primary energy source to supply DC power to electronic devices. Accordingly, the output of the PEMFC/UC/BT hybrid system is recorded at the DC bus. The system was predicted to supply a constant $12 \mathrm{~V}$ voltage despite the changing current. The current step profile used for this test is shown in Figure 8a. The current was increased by $0.5 \mathrm{~A}$ every $30 \mathrm{~s}$. Figure $8 \mathrm{~b}$ shows the DC bus voltage output of the system, which was a constant $12 \mathrm{~V}$ for $180 \mathrm{~s}$. This system is thus a good working supply system for the operation of electronic devices. This test demonstrates that the PEMFC/UC/BT hybrid energy management system can handle up to a $2.5 \mathrm{~A}$ current load. However, the DC bus output begins to decrease after $180 \mathrm{~s}$ because of the DC/DC converter used. The $12 \mathrm{~V}$ DC/DC converters can receive an input voltage between $14 \mathrm{~V}$ and $24 \mathrm{~V}$ to produce a constant $12 \mathrm{~V}$ voltage with an efficiency of approximately $90 \%$. Lower input values result in a much lower voltage because the efficiency 
of the DC/DC converter can drop to $30 \%$. The output power of this hybrid system is also shown in Figure $8 \mathrm{~b}$ and demonstrates that this system can provide up to $30 \mathrm{~W}$ for an electronic application.

a)

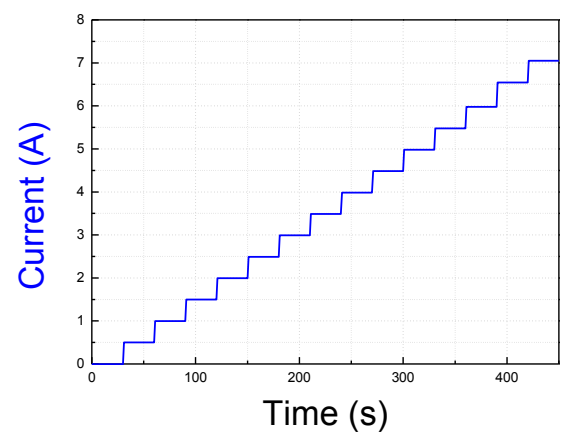

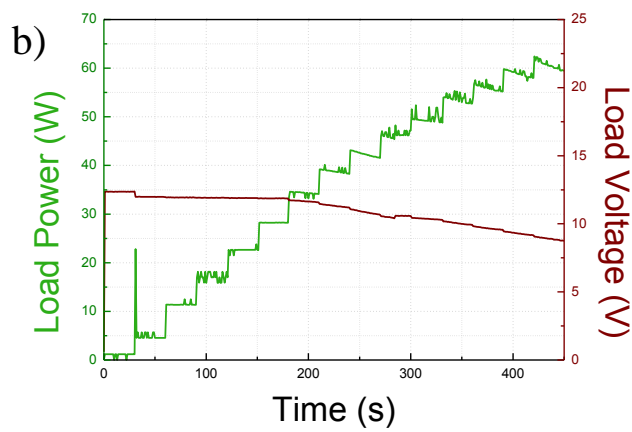

Figure 8. Result of step load for a) current and b) power and voltage

These results indicate that this hybrid energy source is an environmentally friendly energy source that can supply a constant, stable $12 \mathrm{~V}$ voltage up until $2.5 \mathrm{~A}$ current load compare to $1.5 \mathrm{~A}$ in literature [15]. Yan Zhang et al. [15] who also developed an energy management strategy but using only BT as the energy storage unit. Despite using an in-house manufacturing PEMFC, their energy management system, which utilized a simulation developed with the Simulink software, worked well up to a current of 1.5 A, as shown in Figure 9. Due to the unstable voltage output shown in Figure 10a and the limitations of the FC output voltage, the portable PEMFC-BT power system did not produce more than $18 \mathrm{~W}$ of power (Figure 10b). The results presented here show that the PEMFC/UC/BT hybrid energy management system is more capable of supplying power and stable than the PEMFC-BT or PEMFC/UC hybrid system.

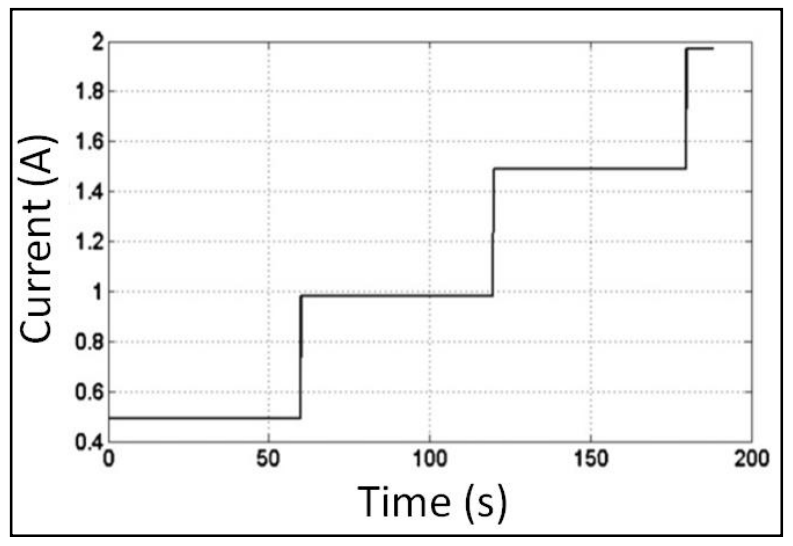

Figure 9. Current step input in PEMFC-BT hybrid system study [15] 
a)

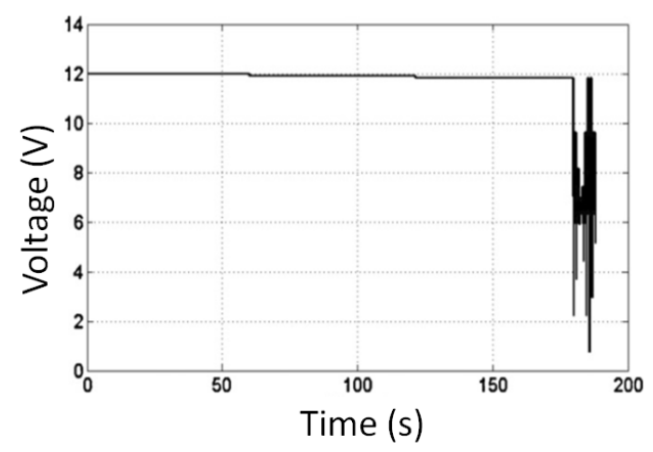

b)

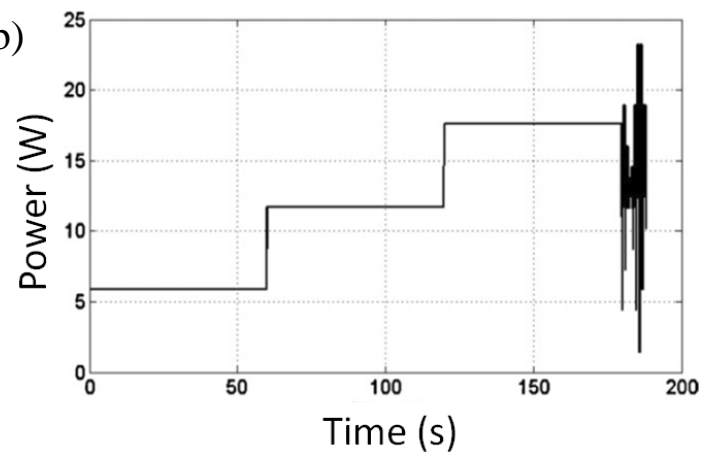

Figure 10. a) Voltage and b) power output of PEMFC-BT hybrid system [15]

\section{Conclusion}

The results of this research convincingly show the benefits of PEMFC hybrid systems. The energy management strategy successfully fulfilled the system requirements during peak power demand, charging and discharging the auxiliary energy sources. This new energy controller is easy to develop, low-cost with few electronic components and employ in the management of the energy sources. This hybrid system did not require full FC power to meet the load demand; the UC and BT helped to reduce the requirements on the FC. In other words, the FC stack is more cost-effective when used in a hybrid system. The transient response of the hybrid system was improved because the auxiliary energy source overcame the limitations of the FC. This system is also more portable compared to that in an electric vehicle because the BT in an electric vehicle must be charged by plugging it into an external energy source, while in hybrid system used FC.

\section{Acknowledgement}

The authors gratefully acknowledge financial support from UKM for Grant UKM-AP-TK-08-2010 and DIP-201205 .

\section{References}

1. Baharuddin, N. A., Rahman, H. A., Muchtar, A., Abu Bakar, S. and Huda, A. (2014). Kesan masa pengendapan dan saiz elektrod lawan dalam penghasilan katod komposit LSCF-SDC karbonat untuk SOFC. Sains Malaysiana, 43(4): 595 - 601.

2. Juhana Jaafar, Ismail, A. F., Matsuura, T. and Mohd Norddin, M. N. A. (2013). Stability of SPEEKtriaminopyrimide polymer electrolyte membrane for direct methanol fuel cell application. Sains Malaysiana, 42(11): 1671 - 1677.

3. Ahmad, A. A., Othman, R., Yusof, F. and Wahab, M. F. A. (2014). A Hybrid enzymatic zinc-air fuel cell. Sains Malaysiana, 43(3): 459 - 465.

4. Arifin, K., Wan Ramli Wan, D. and Mohammad, K. (2014). A novel ruthenium-tungsten bimetallic complex dye-sensitizer for photoelectrochemical cells application. Sains Malaysiana, 43(1): 95 - 101.

5. Panuh, D., Muchtar, A., Norhamidi, M., Majlan, E. H. and Wan Ramli. W. D. (2014). Elektrolit dwi lapisan Sm0.2Ce0.8O1.90 (SDC)/ Y0.25Bi0.75O1.5 (YSB) untuk sel fuel oksida pepejal bersuhu sederhana. Sains Malaysiana, 43(11): 1769 - 1774.

6. Taniguchi, A., Akita, T., Yasuda, K. and Miyazaki, Y. (2004). Analysis of electrocatalyst degradation in PEMFC caused by cell reversal during fuel starvation. Journal of Power Sources, 130(1-2): 42 - 49.

7. Van Vliet, O. P. R., Kruithof, T., Turkenburg, W. C. and Faaij, A. P. C. (2010). Techno-economic comparison of series hybrid, plug-in hybrid, fuel cell and regular cars. Journal of Power Sources, 195(19): 6570 - 6585.

8. Burke, A. F. (2007). Batteries and ultracapacitors for electric, hybrid, and fuel cell vehicles. Proceedings of the IEEE, 95(4): 806 - 820.

9. Hwang, J. J. and Chang, W. R. (2012). Characteristic study on fuel cell/battery hybrid power system on a light electric vehicle. Journal of Power Sources, 207: 111 - 119. 
10. Khaligh, A. and Zhihao, L. (2010). Battery, ultracapacitor, fuel cell, and hybrid energy storage systems for electric, hybrid electric, fuel cell, and plug-in hybrid electric vehicles: State of the art. IEEE Transactions on Vehicular Technology, 59(6): 2806 - 2814.

11. Schaltz, E., Khaligh, A. and Rasmussen, P. O. (2008). Investigation of battery/ultracapacitor energy storage rating for a fuel cell hybrid electric vehicle. Vehicle Power and Propulsion Conference: $1-6$.

12. Erdinc, O., Vural, B. and Uzunoglu, M. (2009). A wavelet-fuzzy logic based energy management strategy for a fuel cell/battery/ultra-capacitor hybrid vehicular power system. Journal of Power Sources. 194(1): 369 - 380.

13. Bernard, J., Hofer, M., Hannesen, U., Toth, A., Tsukada, A., Büchi, F. N. and Dietrich, P. (2011). Fuel cell/battery passive hybrid power source for electric powertrains. Journal of Power Sources, 196(14): 5867 . 5872 .

14. Uzunoglu, M. and Alam, M. S. (2007). Dynamic modeling, design and simulation of a PEM fuel cell/ultracapacitor hybrid system for vehicular applications. Energy Conversion and Management, 48(5): 1544 - 1553.

15. Zhang, Y. and Zhou, B. (2011). Modeling and control of a portable proton exchange membrane fuel cellbattery power system. Journal of Power Sources, 196(20): 8413 - 8423. 